\title{
Contribuições, potencialidades e dificuldades do ambiente Google Sala de Aula para
}

\section{o processo ensino e aprendizagem}

\author{
Contributions, potentials and difficulties of the Google Classroom environment for the teaching
} and learning process

Aportes, potencialidades y dificultades del entorno Google Classroom para el proceso de enseñanza y aprendizaje

\section{Resumo}

As tecnologias da informação e comunicação - TIC estão cada vez, mais presentes no cotidiano de toda população interferindo em suas relações sociais, profissionais e educacionais. Dentre os recursos interativos propiciados pelas TIC, estão os ambientes virtuais de aprendizagem, ciberespaços que permitem divulgar conteúdos e a interação virtual. Assim, o presente artigo apresenta resultados parciais de uma pesquisa de doutorado ${ }^{1}$, e tem como objetivo investigar quais as contribuições, potencialidades e dificuldades do ambiente Google Sala de Aula para o processo ensino e aprendizagem, de acordo com os alunos do $4^{\circ}$ ano do Curso de Administração Integrado em uma escola da rede pública do município de Paranavaí. A metodologia adotada é de natureza qualitativa, do tipo observação participante, na qual foi implementada uma sequência didática, utilizando os recursos do Google Sala de Aula, associado ao uso de simulações. Posteriormente foi aplicado um questionário pós-teste cujos resultados apresentam-se neste artigo. Entre as principais vantagens do ambiente elencadas pelos alunos estão: facilitar a aprendizagem; possibilitar uma diversificação metodológica ao aliar o uso dos recursos tecnológicos; a organização e praticidade do ambiente; e a comunicação e interação; E como desvantagens: dificuldade de acesso à internet e no uso de seus recursos. Concluiu-se que o uso do ambiente virtual de aprendizagem Google Sala de Aula, pode ser uma excelente ferramenta para fins didático-pedagógico, se for utilizado de maneira planejada, pois pode vir a facilitar a aprendizagem, possibilitar uma diversificação metodológica; auxiliar na organização de conteúdos e na interação entre os participantes.

Palavras-chave: TIC; Recursos digitais; Ambientes virtuais; Ensino de Biologia.

\begin{abstract}
Information and communication technologies - ICT are increasingly present in the daily lives of the entire population, interfering in their social, professional and educational relationships. Among the interactive resources provided by ICT are virtual learning environments, cyberspaces that allow the dissemination of content and virtual interaction. Thus, this article presents partial results of a doctoral research, and aims to investigate the contributions, potentials and difficulties of the Google Classroom environment for the teaching and learning process, according to the 4th year students of the course. Integrated Administration in a public school in the city of Paranavaí. The methodology adopted is of a qualitative nature, of the participant observation type, in which a didactic sequence was implemented, using the resources of Google Classroom, associated with the use of simulations. Subsequently, a post-test questionnaire was applied, the results of which are presented in this article. Among the main advantages of the environment listed by students are: facilitate learning; enable a methodological diversification by combining the use of technological resources; the organization and practicality of the environment; and communication and interaction; And as disadvantages: difficulty in accessing the internet and using its resources. It was concluded that the use of the virtual learning environment Google Classroom, can be an excellent tool for didactic-pedagogical purposes, if used in a
\end{abstract}

\footnotetext{
${ }^{1}$ Pesquisa de Doutorado intitulada "Google Sala de Aula, as simulações e suas contribuições para a aprendizagem significativa dos conceitos de genética"; do Programa de Pós-graduação em Educação para a Ciência e a Matemática, da Universidade Estadual de Maringá (UEM).
} 
planned way, as it can facilitate learning, enable a methodological diversification; assist in the organization of content and interaction between participants.Incluir o resumo em inglês.

Keywords: ICT; Digital resources; Virtual environments; Biology teaching.

\begin{abstract}
Resumen
Tecnologías de la información y la comunicación - Las TIC están cada vez más presentes en la vida cotidiana de toda la población, interfiriendo en sus relaciones sociales, profesionales y educativas. Entre los recursos interactivos que brindan las TIC se encuentran los entornos virtuales de aprendizaje, ciberespacios que permiten la difusión de contenidos y la interacción virtual. Así, este artículo presenta resultados parciales de una investigación de doctorado, y tiene como objetivo investigar las aportaciones, potencialidades y dificultades del entorno Google Classroom para el proceso de enseñanza y aprendizaje, según los alumnos de $4^{\circ}$ curso de la asignatura. Administración integrada en una escuela pública en la ciudad de Paranavaí. La metodología adoptada es de carácter cualitativo, de tipo observación participante, en la que se implementó una secuencia didáctica, utilizando los recursos de Google Classroom, asociada al uso de simulaciones. Posteriormente se aplicó un cuestionario post-test, cuyos resultados se presentan en este artículo. Entre las principales ventajas del entorno enumeradas por los estudiantes se encuentran: facilitar el aprendizaje; posibilitar una diversificación metodológica combinando el uso de recursos tecnológicos; la organización y practicidad del medio ambiente; y comunicación e interacción; Y como desventajas: dificultad para acceder a internet y utilizar sus recursos. Se concluyó que el uso del entorno de aprendizaje virtual Google Classroom, puede ser una excelente herramienta con fines didáctico-pedagógicos, si se utiliza de forma planificada, ya que puede facilitar el aprendizaje, posibilitar una diversificación metodológica; ayudar en la organización del contenido y la interacción entre los participantes.
\end{abstract}

Palabras clave: TIC; Recursos digitales; Entornos virtuales; Enseñanza de la Biología.

\title{
1. Introdução
}

As Tecnologias da Informação e Comunicação (TICs) estão presentes atualmente nos diferentes espaços e contextos da sociedade, incluindo a escola, proporcionando assim, mudanças significativas no cotidiano das pessoas, facilitando o acesso à informação, influenciando as relações interpessoais, o mercado de trabalho e a educação. Dessa maneira, vivenciamos "uma nova forma de organização econômica, social, política e cultural, identificada como Sociedade da Informação (SI), que comporta novas maneiras de trabalhar, de comunicar-se, de relacionar-se, de aprender, de pensar e, em suma, de viver (Coll \& Monereo, 2010, p. 15).

Neste contexto, o alcance aos meios de comunicação e recursos tecnológicos se tornou mais acessível, tendo em vista que boa parte dos alunos ingressam na escola já possuindo celular e/ou microcomputador com acesso à internet. Assim, "fora do ambiente escolar, contemporaneamente muitos alunos têm acesso a diversos recursos que permitem o entretenimento, a obtenção de informações, ao conhecimento de lugares distantes, à interação e à comunicação a nível mundial, em ambientes virtuais" [...] (Gianotto, 2016, p. 17). Existindo, por exemplo, a possibilidade de passeios virtuais à museus, biblioteca, parques e instituições de várias partes do mundo que estejam disponíveis de forma online.

Sendo assim, compete ao docente utilizar a seu favor esse processo de interação do educando com as mídias, valendose da grande quantidade de vídeos, imagens, animações, simulações, jogos na internet e ambientes virtuais que podem ser utilizados como recursos didáticos nas aulas nas diversas áreas de conhecimento. Pois, o "uso do computador, na educação, tem sido utilizado tanto para ensinar sobre recursos computacionais quanto para ensinar praticamente qualquer assunto utilizando programas, simulações e animações" (Gianotto, 2016, p. 7).

Dessa forma, surgiu o desafio de se pesquisar a influência que as mídias exercem sobre os educandos como recurso didático no processo ensino e aprendizagem, aliando o uso de um ambiente virtual de aprendizagem, com a inserção de objetos de aprendizagem, em conjunto com a atividade de escrita e a interação entre os alunos. Por conseguinte, implementar uma estratégia metodológica que permitisse a participação de todos, minimizando dificuldades, mas acima de tudo, a busca de uma aprendizagem significativa.

Portanto, perante o uso das novas tecnologias de informação e comunicação, cada vez mais presentes em sala de aula, o presente trabalho baseia-se na seguinte questão de investigação: Quais as contribuições, potencialidades e dificuldades da 
utilização do Google sala de aula para o processo ensino e aprendizagem de genética?

Dessa maneira, este artigo tem como objetivo investigar o ponto de vista dos alunos do curso técnico integrado em Administração sobre as contribuições, potencialidades e dificuldades do ambiente Google Sala de Aula para o processo ensinoaprendizagem. Salienta-se que, nesta pesquisa, o conteúdo de biologia trabalhado foi o de genética.

\subsection{Tecnologias de Informação e Comunicação - TIC}

A tecnologia em si é compreendida como "o conjunto de conhecimentos e princípios científicos que se aplicam ao planejamento, à construção e à utilização de um equipamento em um determinado tipo de atividade" (Kenski, 2012, p. 15-16). Assim, desde um simples lápis até um sofisticado celular, ambos são considerados produtos da tecnologia.

Miranda (2007, p. 42) por sua vez, elucida que o termo TIC não se limita apenas "aos recursos técnicos usados no ensino, mas sim, a todos os processos e concepção, desenvolvimento e avaliação da aprendizagem". Dessa forma, acrescenta a autora, as TIC referem-se ao conjunto integrado da tecnologia computacional com a tecnologia das telecomunicações, tendo na Internet, ou seja, na rede mundial de computadores, a sua a maior relevância. Por isso, quando as tecnologias são utilizadas para propósitos educacionais, especificamente para "apoiar e melhorar a aprendizagem dos alunos e desenvolver ambientes de aprendizagem, podemos considerar as TIC como um subdomínio da Tecnologia Educativa" (Miranda, 2007, p. 43).

Nesse sentido, valida Coll e Monereo (2010, p. 17) ao afirmar que dentre todas as tecnologias criadas pela humanidade, as TIC são consideradas as mais importantes, pois influenciam em "praticamente todos os âmbitos de atividade dos indivíduos, desde as formas e práticas de organização social até o modo de compreender o mundo, de organizar essa compreensão e de transmiti-la para outras pessoas" (Coll \& Monereo, 2010, p.17). Essa junção da informação e da comunicação possibilita a constituição de novos ambientes de aprendizagens e de interação, acrescenta Hamze (2011).

À vista disso, "na sociedade contemporânea, existe a necessidade de se refletir sobre metodologias que proporcionem ações pedagógicas que promovam a participação ativa dos alunos no processo de aprendizagem, e assim, possibilitem a interação com os colegas e com o objeto de estudo" (Lima et al., 2021, p. 2).

Portanto, a utilização de ambientes virtuais e de objetos de aprendizagem podem ser primordiais para a construção do conhecimento, visto que, integram processos colaborativos de ensino e aprendizagem, em razão de serem elaborados a partir de uma problemática, estimulando o raciocínio dos alunos, e auxiliando assim, na formação de cidadãos críticos.

\subsection{Ambientes Virtuais de Aprendizagem - AVA}

São considerados Ambientes Virtuais de Aprendizagem (AVA), os "[...] sistemas baseados em tecnologia de Internet que rodam por meio de um servidor e são acessados por um navegador web" (Ferreira, 2010, p. 60). Trata-se de um conjunto de "mídias, textos, vídeos, imagens, sons que vão fazer uso do ciberespaço para mediar o processo de ensino-aprendizagem, ou seja, mídias que utilizam o ciberespaço para veicular conteúdo e permitir interação entre os atores do processo educativo" (Pereira, 2007, p. 5).

Também conhecidos como LMS “Learning Management System”, conforme Silva (2010), os AVA são ambientes de gestão e construção integradas de informação, comunicação e aprendizagem online, numa hiperinterface, agregando interfaces síncronas e assíncronas integradas, na qual o docente pode disponibilizar conteúdos e atividades, acompanhando o rendimento individual e coletivo dos alunos. Estes podem estudar, ter encontros virtuais e interagir a qualquer momento com os demais colegas e o docente, podendo tomar decisões, analisar, interpretar, observar, testar hipóteses, elaborar e colaborar com conteúdo. Enquanto isso, o professor, propicia o acesso às informações, disponibiliza conteúdo didático multimídia, objetos de aprendizagem e materiais complementares. 
Assim, ao usar as TIC, elucida Moreira (2018), pode-se impelir mudanças na forma de estruturar o ensino e a escolha dos recursos tecnológicos, podendo organizar as atividades de forma síncrona e assíncrona. A atividade presencial síncrona é aquela que ocorre de forma simultânea no mesmo tempo e lugar em que se desenvolve a atividade de ensino. Por sua vez, a não presencial síncrona, é aquela que ocorre no mesmo tempo, porém em lugares distintos; não sendo imprescindível a presença física do professor e alunos. Além disso, também é possível o desenvolvimento de atividades de interação entre professor e alunos, sem precisamente estarem no mesmo local, nem ao mesmo tempo, numa comunicação assíncrona. Dessa forma, a "dinâmica das interfaces pode gerar a presença online ou presença "virtual", capaz de formar as redes sociais de docência e aprendizagem. Permite a experiência da presença, mesmo com indivíduos geograficamente dispersos. De modo síncrono ou assíncrono" (Silva, 2010, p. 49).

As ferramentas síncronas, conforme Silva (2018), possibilitam uma intercomunicação simultânea, ou seja, em tempo real, entre os participantes, por meio do "chat", mesmo que estes estejam em diversos locais. As ferramentas assíncronas, por sua vez, permitem a interação em tempos distintos, através de e-mail, com trocas de mensagens entre uma ou mais pessoas e o fórum, no qual são discutidos temas de interesse dos participantes sem a necessidade de que todos os participantes estejam conectados simultaneamente.

Nesse novo cenário educacional, esclarece Gianotto (2016), o professor exerce o papel de mediação do processo de ensino e aprendizagem, disponibilizando a base educacional adequada à realização de atividades construtivas pelos alunos com utilização das TIC. Para isso, o professor deve planejar todas as atividades, criando condições para promover a interação entre si e os alunos e entre os mesmos (Mauri \& Onrubia, 2010).

Essa interação proporcionada pelos AVA, afirma Silva (2018), revolucionaram o processo ensino e aprendizagem, tornando-o mais dinâmico e interativo, pois possibilitam unir em um mesmo ambiente, diversas mídias e ferramentas, tais como textos, vídeos, fóruns e chats, entre outros. Tendo em vista, que estas disponibilizam "um conjunto de ferramentas que auxiliam na comunicação, no acesso, no controle dos usuários do sistema em geral e na aprendizagem dos alunos" (Silva, 2018, p. 7).

\subsection{Google Sala de Aula}

No cotidiano é comum fazer-se uso de serviços do Google, tais como pesquisa, e-mail, drive, mapas, agenda, entre outros. Professores e alunos o utilizam com frequência para a busca de materiais diversos, tais como textos, imagens, apresentações, vídeos e outros. Mas além disso, a empresa oferece uma plataforma gratuita para uso educacional, que pode ser utilizada por professores e alunos, tanto no interior da sala de aula, quanto externamente.

Dentre os diversos AVA disponíveis na atualidade, o Google "Classroom" ou Google Sala de Aula é uma plataforma virtual, mantida pela empresa Google, que pode ser acessada através de diferentes dispositivos, tais como computador, "tablet" ou celular. Possuindo versões para plataforma com acesso no computador ou na forma de aplicativo, acessível para celulares e tabletes, tanto para androides como iphones, o que facilita o acesso nos mais variados ambientes, como na escola, casa ou trabalho, por exemplo. Por ser compatível com diversos sistemas operacionais e plataformas de navegação, viabiliza o acesso a plataforma por diferentes aparelhos. Para ter acesso à esta plataforma, o usuário precisa estar logado em uma conta gmail (Figura 1). 
Figura 1 - Acesso ao ambiente Google Sala de Aula usando computador e smartphone.

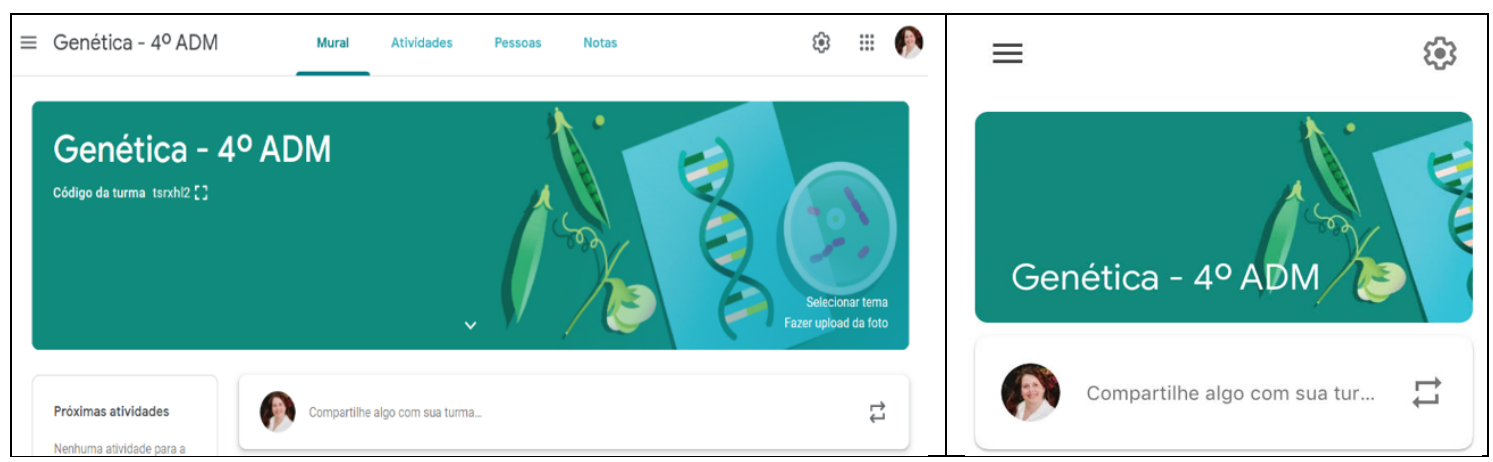

Fonte: Autores (2020). Retirada de https://classroom.google.com/c/Mjg5MzQzMjA2ODJa.

No contexto escolar, essa ferramenta pode auxiliar professores e alunos "a organizar as tarefas, aumentar a colaboração e melhorar a comunicação" (Google, 2020). Trata-se de um serviço gratuito disponibilizado para escolas, universidades e usuários que tenham uma conta do Gmail, no qual professores e alunos se conectam a fim de interagir tanto no ambiente escolar, como fora dele. "O Google Sala de aula economiza tempo e papel, além de facilitar a criação de turmas, distribuição de tarefas, comunicação e organização” (Google Play, 2019).

Essa plataforma educacional do Google foi criada em 2014, e por meio dessa ferramenta, conforme Silva e Netto (2018, p. 120), permite que o professor possa "gerenciar conteúdo, simplificar a criação, distribuição e avaliação de trabalhos escolares, bem como características de interatividade e colaboração entre os agentes do processo de aprendizagem”. Essas funções existentes na plataforma, acrescentam os autores, favorecem a troca de conhecimentos entre os participantes do processo pelas diversas formas de comunicação entre eles. Trata-se de "uma ferramenta que permite a criação de grupos e turmas para compartilhamento virtual de informações e documentos" (Araújo, 2016, p. 34).

Dentre as principais utilidades apontadas por Silva (2018) estão (Quadro 1):

Quadro 1 - Possibilidades de uso do Google Sala de Aula.

\begin{tabular}{|l|l|}
\hline Usuário & O que você pode fazer com o Google Sala de aula. \\
\hline Professores & $\begin{array}{l}\text { Criar e gerenciar turmas, tarefas e notas. } \\
\text { Dar feedback direto e em tempo real e atribuir notas. }\end{array}$ \\
\hline Alunos & $\begin{array}{l}\text { Acompanhar os materiais e as tarefas da turma. } \\
\text { Compartilhar e interagir no mural da turma ou por e-mail. } \\
\text { Enviar tarefas. } \\
\text { Receber notas e feedback. }\end{array}$ \\
\hline
\end{tabular}

Fonte : Silva (2018, p. 10). Adaptado do Support Google.

Dessa forma, pode ser de grande valia como recurso educacional, pois apresenta as seguintes características: é de fácil acesso e configuração, sendo possível adicionar diretamente o aluno ou compartilhar um código para participarem da turma; economiza tempo, permitindo que os professores criem, reformulem, corrijam e atribuam notas às atividades disponibilizadas; aperfeiçoa a organização, pois as atividades ficam em uma página específica para tarefas e os materiais didáticos ficam alocados em pastas no Google Drive; melhora a comunicação, permitindo aos professores enviarem avisos e iniciarem debates com o grupo instantaneamente, e aos alunos responderem aos questionamentos de compartilharem recursos com os demais colegas; é acessível e seguro, gratuito, não exibindo anúncios, nem utilizando os dados dos alunos para fins publicitários (Google Play, 2019).'

O uso desta plataforma possibilita vários benefícios (Quadro 2), entre os quais: 
Quadro 2 - Principais benefícios sobre o uso do Google Sala de Aula.

\begin{tabular}{|l|l|}
\hline Benefício & Descrição \\
\hline $\begin{array}{l}\text { Fácil } \\
\text { configuração }\end{array}$ & $\begin{array}{l}\text { Os professores podem cadastrar uma turma e convidar alunos e professores auxiliares. No } \\
\text { mural da turma, eles compartilham informações, como tarefas, avisos e perguntas. }\end{array}$ \\
\hline $\begin{array}{l}\text { Poupa tempo em um } \\
\text { papel }\end{array}$ & $\begin{array}{l}\text { Os professores podem distribuir tarefas, se comunicar e manter a organização em um } \\
\text { único lugar. }\end{array}$ \\
\hline $\begin{array}{l}\text { Mais } \\
\text { organização }\end{array}$ & $\begin{array}{l}\text { Os alunos podem ver as tarefas na página "Pendentes", no mural da turma ou na agenda } \\
\text { da turma. Todos os materiais didáticos são automaticamente colocados em pastas do } \\
\text { Google Drive. }\end{array}$ \\
\hline $\begin{array}{l}\text { Comunicação e e e } \\
\text { feedback } \\
\text { aprimorados }\end{array}$ & $\begin{array}{l}\text { Os professores podem criar tarefas, enviar avisos e iniciar instantaneamente debates com } \\
\text { a turma. Os alunos podem compartilhar recursos um com os outros e interagir no mural da } \\
\text { turma ou por e-mail. Os professores também podem ver rapidamente quem concluiu ou } \\
\text { não um trabalho, dar feedback direto e em tempo real e atribuir notas. }\end{array}$ \\
\hline $\begin{array}{l}\text { Funciona com } \\
\text { aplicativos }\end{array}$ & $\begin{array}{l}\text { O Google Classroom funcionar com os seguintes recursos: Docs Google, Google Agenda, } \\
\text { Gmail, Google Drive, Google Forms, entre outros. }\end{array}$ \\
\hline $\begin{array}{l}\text { Acessível } \\
\text { seguro }\end{array}$ & $\begin{array}{l}\text { O Google Clasrrom é gratuito, seu suporte afirma que não exibe anúncios e não uso o } \\
\text { conteúdo do professor ou os dados dos alunos para fins publicitários. }\end{array}$ \\
\hline
\end{tabular}

Fonte: Silva (2018, p. 9).

Dentre os principais aspectos positivos elencados quadro acima a respeito do Google sala de aula como recursos de um ambiente cooperativo, pode-se destacar:

A capacidade para armazenamento de e-mails e arquivos ilimitada, o sistema de comunicação via e-mail, Gmail; a possibilidade de encaminhamento de mensagens instantâneas, via Hangouts; o calendário que permite trabalhar com agendamentos; a praticidade da ferramenta para ambiente de Sala de Aula; a possibilidade de criação de Websites e o incentivo à participação em redes sociais (Araújo, 2016, p. 35).

Dessa forma, o Google sala de aula é um ambiente familiar aos alunos, afirma Araújo (2016) tendo em vista, que ele se assemelha a uma rede social, sendo possível compartilhar e comentar, bem como, apresenta integração com os serviços do Google, tais como, o e-mail e o drive.

No entanto, a principal característica do Google sala de aula está na "na ampliação do espaço-tempo, o que torna o processo de aprendizagem contínuo e dinâmico" (Silva \& Netto, 2018, p.120). A capacidade de interação e comunicação, entre professor e alunos, a qualquer tempo e local, ampliam o processo ensino aprendizagem para além do ambiente da sala de aula. Desse modo, acredita-se que "o uso da plataforma é de fácil aceitação e bem utilizada por professores e estudantes conectados no mundo informatizado, a julgar por seu fácil acesso e características colaborativas" (Silva \& Netto, 2018, p. 120).

Deste modo, percebe-se conforme Prandini (2009), que a tecnologia pode expandir a capacidade de comunicação entre professores e alunos, aumentando as dimensões de espaço e tempo em que essa interação pode ocorrer, tanto de forma síncrona ou assíncrona, oportunizando modalidades comunicativas distintas.

Outro aspecto extremamente positivo do Google sala de aula, é que o professor pode organizar todo seu material (textos, imagens, vídeos e atividades), usando diferentes opções de ordem, como a cronológica ou por tema. Assim, "o professor ainda poderá ter todo seu material/conteúdo organizado em uma plataforma, e ainda poderá estar compartilhado com seus alunos, postando atividades, com diferentes mídias, promovendo interação e levando assim a aprendizagem colaborativa" (Silva, 2018, p. 8). Consequentemente, oportuniza ao educador, o acesso a sua sala de aula, a qualquer tempo e lugar, desde que conectado à internet, criando um ponto de discussão com a turma, no qual poderá ter cunho educacional.

Destarte, o objetivo da ferramenta, contribui Araújo (2016), é auxiliar os docentes a economizar tempo, mantendo as turmas organizadas e aperfeiçoando a comunicação com os alunos. Através dela é possível criar e compartilhar atividades online, assim, como corrigir e atribuir a nota a cada uma delas. O docente realiza a tarefa utilizando o próprio Google Sala de aula ou Google Doc., com a vantagem de que todo o conteúdo fica salvo no Google Drive, otimizando a consulta e acesso ao 
conteúdo a qualquer momento. Por conseguinte, "o professor pode criar turmas, compartilhar documentos, propor tarefas individuais ou coletivas, enviar feedbacks e propor discussões. Os alunos podem compartilhar recursos e trocar ideias". (Araújo, 2016, p. 34).

$\mathrm{O}$ ambiente apresenta algumas desvantagens, entre as quais, a falta de estrutura na "disponibilização dos recursos, sendo prático apenas para atividades do dia a dia, a dependência do funcionamento da Internet, a obrigatoriedade de existir um domínio associado às Google Apps Educação e a obrigatoriedade de os alunos possuírem um e-mail institucional" (Araújo, 2016, p. 36). Sendo assim, é necessário que o professor conheça bem a ferramenta que irá utilizar, assim como a estrutura de suporte para esse uso.

O ambiente virtual Google sala de aula pode ser enriquecedor, didáticamente, se for utilizado de maneira planejada, visando estabelecer "novas metodologias interativas onde se possa compartilhar materiais didáticos de forma dinâmica, bem como, propiciar a interação em tempo real entre professores e alunos" (Araújo, 2016, p. 18).

Dessa maneira, é possível utilizar as ferramentas deste ambiente virtual para aperfeiçoar o processo ensino aprendizagem das várias áreas do conhecimento. Pois, seu uso "pode despertar o interesse do aluno por meio de um trabalho lúdico e prazeroso, que o levará a uma maior socialização e um processo de relacionamento interpessoal, o qual propiciará o aprendizado coletivo" (Araújo, 2016, p. 17).

A própria Base Nacional Comum Curricular (BNCC), ressalta a importância da Cultura Digital, apontando-a como a quinta competência geral da Educação Básica, necessária na inter-relação e desdobramento do tratamento didático em vista ao processo ensino e aprendizagem dos educandos, pois,

Compreender, utilizar e criar tecnologias digitais de informação e comunicação de forma crítica, significativa, reflexiva e ética nas diversas práticas sociais (incluindo as escolares) para se comunicar, acessar e disseminar informações, produzir conhecimentos, resolver problemas e exercer protagonismo e autoria na vida pessoal e coletiva (Brasil, 2018, p. 9.

\section{Metodologia}

A metodologia adotada nesta pesquisa é de natureza qualitativa, por meio da observação participante, sendo submetida à apreciação do comitê Permanente de Ética em Pesquisa com Seres Humanos (COPEP) e aprovada sob o ${ }^{\circ}$ 13274719.3.0000.0104. Pois, esta metodologia tem o intuito de "aprofundar a compreensão dos fenômenos que investiga a partir de uma análise rigorosa e criteriosa desse tipo de informação" (Moraes \& Galiazzi, 2011, p.11).

Primeiramente foi realizada uma pesquisa bibliográfica sobre os recursos educacionais, tais como ambientes virtuais, especialmente o Google Sala de Aula e as simulações e sua contribuição no ensino de Genética. O referencial teórico consiste no "levantamento, seleção, fichamento e arquivamento de informações relacionadas à pesquisa" (Amaral, 2007, p.5).

Num segundo momento, implementou-se numa turma do $4^{\circ}$ ano do Curso de Administração nível médio de uma escola da rede pública do município de Paranavaí-PR, parte de uma sequência didática intitulada "Objetos de aprendizagem como recurso didático no processo ensino-aprendizagem de genética" (Bilthauer \& Takasusuki (2012), sobre a construção dos conceitos básicos de genética mendeliana (Quadro 3). A Sequência didática é compreendida como "um modo de o professor organizar as atividades de ensino em função de núcleos temáticos e procedimentais" (Araújo, 2013, p. 323). 
Quadro 3 - Simulações utilizadas na implementação.

\begin{tabular}{|c|c|c|}
\hline Simulação & Objetivo da Simulação & Objetivo na Proposta \\
\hline $\begin{array}{l}\text { Atividade } 1-\mathrm{O} \\
\text { Caso do rebanho } \\
\text { de Jaco }\end{array}$ & $\begin{array}{l}\text { Reconhecer que individuos que } \\
\text { apresentam um mesmo fenótipo podem } \\
\text { possuir genótipos diferentes. }\end{array}$ & $\begin{array}{l}\text { Apresentação dos conceitos de Genética clássica e de hereditariedade, por meio } \\
\text { de uma situação problema do personagem biblico Jacó, com o objetivo de } \\
\text { reconhecer que individuos que apresentam um mesmo fenótipo, podem } \\
\text { apresentar genótipos diferentes, além de elaborar suposições sobre o fenômeno } \\
\text { estudado. } \\
\text { Elaboração de uma tabela utilizando o Google Planilhas sobre os cruzamentos } \\
\text { e a quantidade de fillhotes produzidos e suas respectivas cores. }\end{array}$ \\
\hline $\begin{array}{l}\text { Atividade } 3 \text { - As } \\
\text { ervilhas ajudariam } \\
\text { Jacó? }\end{array}$ & $\begin{array}{l}\text { Reconhecer se os individuos que } \\
\text { apresentam um mesmo fenótipo podem } \\
\text { expressar genótipos diferentes e propõe } \\
\text { hipoteses sobre berança aplicando as } \\
\text { ideias de Mendel, além de testar } \\
\text { hipótese sobre berança. }\end{array}$ & $\begin{array}{l}\text { Exposição dos principios genéticos de Mendel, por atividades elaboradas a } \\
\text { partir de uma situação problema vivenciada pela personagem biblico Jacó, com } \\
\text { o objetivo de reconhecer se os individuos que apresentam um mesmo fenótipo } \\
\text { podem expressar genótipos diferentes e propóe hipóteses sobre berança } \\
\text { aplicando as ideias de Mendel, além de testar hipótese sobre herança. } \\
\text { Elaboração de uma tabela utilizando o Google Planilhas sobre os cruzamentos } \\
\text { e a quantidade de fillhotes produzidos e suas respectivas cores. } \\
\text { Resolução de questões sobre os cruzamentos usando o Google Documentos. }\end{array}$ \\
\hline $\begin{array}{l}\text { Atividade } 4-\hat{\mathrm{E}} \\
\text { hora de colocar as } \\
\text { coisas no luger. }\end{array}$ & $\begin{array}{l}\text { Relacionar os conceitos de célula, gene, } \\
\text { alelos, DNA e cromossomo, elaborando } \\
\text { um mapa conceitual. }\end{array}$ & $\begin{array}{l}\text { Elaboração um mapa dos conceitos sobre genes, cromossomos e DNA. } \\
\text { Inserção da atividade no Google Apresentaçōes; }\end{array}$ \\
\hline $\begin{array}{l}\text { Atividade } 5- \\
\text { Mendel não sabia } \\
\text { disso... }\end{array}$ & $\begin{array}{l}\text { Elaborar uma sequência relacionando os } \\
\text { seguintes conceitos: hereditariedade, } \\
\text { DNA, mitose, meiose, sintese de } \\
\text { proteinas, etc. }\end{array}$ & $\begin{array}{l}\text { Elaboração um pequeno video, a partir de imagens e legendas disponiveis em } \\
\text { uma tela, com o objetivo de estabelecer uma sequência aos processos básicos } \\
\text { da hereditariedade, tais como a mitose, a meiose e a sintese de proteinas. }\end{array}$ \\
\hline $\begin{array}{l}\text { Atividade } 6- \\
\text { Vendo } 6 \text { mundo } \\
\text { com outros olhos }\end{array}$ & $\begin{array}{l}\text { Compreender situsçòes especiais de } \\
\text { genes recessivos ligados aos } \\
\text { cromossomos sexusis, especialmente os } \\
\text { situados no cromossomo } \mathrm{X} \text {, como } \\
\text { daltonismo. }\end{array}$ & $\begin{array}{l}\text { Explanação sobre berança ligada aos cromossomos sexuais, especialmente os } \\
\text { situados no cromossomo X, como o daltonismo } \\
\text { Resolução de atividade relacionando as caracteristicas fenotipicas e genotipicas } \\
\text { de individuos daltônicos e cálculo das probabilidades de ocorrência do } \\
\text { daltonismo a partir de uma situação problema do cotidiano. }\end{array}$ \\
\hline
\end{tabular}

Fonte: Autores (2020).

A implementação da pesquisa teve início no dia 12 de março de 2019 e finalizou em 04 de junho de 2019, sendo realizada no primeiro trimestre deste ano letivo, aplicada em 12 encontros semanais, com duração de 50 minutos, realizadas no próprio turno durante as aulas de Biologia.

Para a sua aplicação, optou-se pela elaboração de uma plataforma virtual pois, além de abrir nos computadores da sala de informática da própria escola, ela também dispõe do formato aplicativo, sendo possível acessá-la em celular, nos diversos sistemas operacionais. Por ser um ambiente virtual, possibilitou à pesquisadora a construção passo-a-passo de seu conteúdo, explicações e instruções pertinentes. Valente (2009) denomina esse sentimento de empowerment, segundo o qual quando é dada a oportunidade para a pessoa compreender o que está elaborando, este tem a sensação de ser capaz de produzir algo considerado impossível.

Para a execução da proposta criou-se um ambiente virtual na plataforma Google Sala de Aula, a partir da qual, implementou-se a referida sequência didática, com a inserção de textos e atividades, explorando animações, simulações e vídeos sobre os conceitos básicos de genética. Por meio deste ambiente, explorou-se recursos como a apresentação de conteúdo, proposições de atividades, questões, instrumentos de avaliação e formas de interação como chats.

Após a implementação da sequência didática, aplicou-se um questionário pós-teste, elaborado pela autora, com dezesseis questões mistas (objetivas e subjetivas, com intuito de investigar junto aos alunos as contribuições, potencialidade e dificuldades do ambiente Google Sala de Aula para o processo ensino e aprendizagem. Para este artigo foram selecionadas três, cujo os resultados são apresentados na sequência.

\section{Resultados e Discussão}

O primeiro aspecto levantado com os alunos foram quais as contribuições eles acreditam que o ambiente Google Sala de Aula possibilita para a construção da aprendizagem. Nesse sentido, sete alunos indicaram em primeiro lugar que facilita a 
aprendizagem; três disseram que possibilitam uma diversificação metodológica ao aliar o uso dos recursos tecnológicos; dois mencionaram a organização e praticidade do ambiente; um citou o processo de comunicação e interação tanto entre os próprios alunos, quanto com a professora; um mencionou a dificuldade em abstrair em conhecimento; e um referiu-se à dificuldade da administração do tempo para a execução das atividades (Gráfico 1).

Gráfico 1 - Contribuições do ambiente Google Sala de Aula para a construção da aprendizagem.

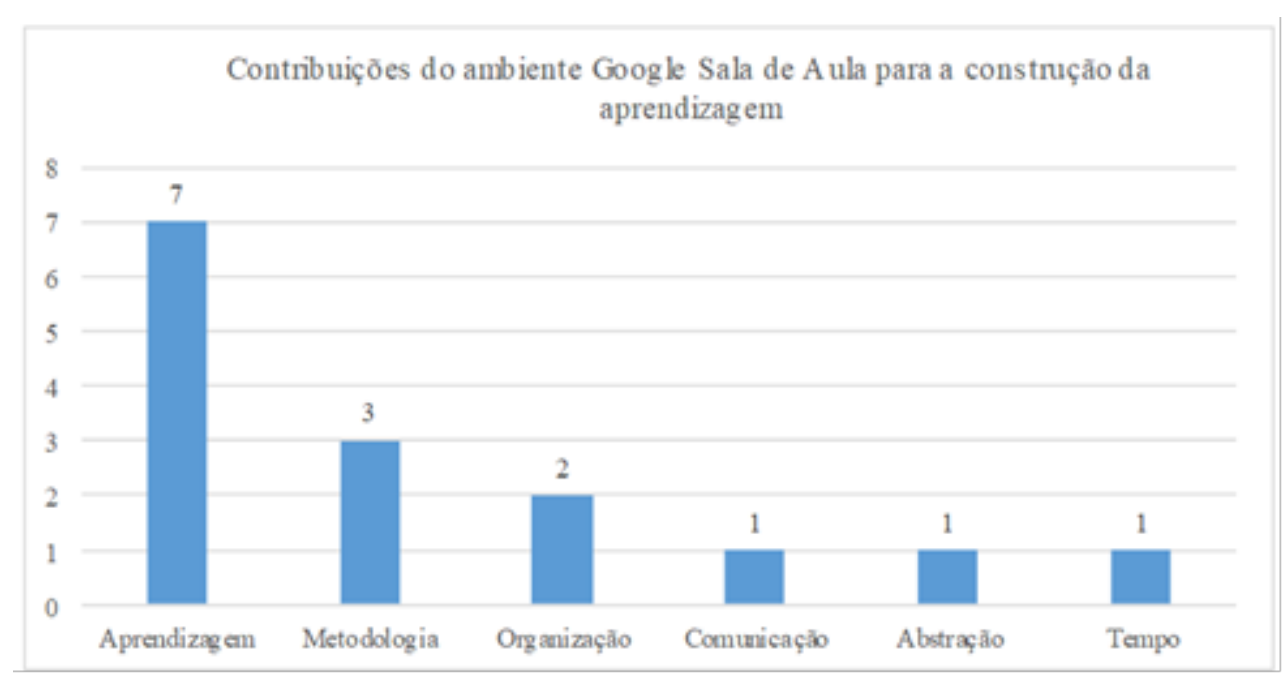

Fonte: Autores (2020).

Esses apontamentos realizados pelos alunos são concernentes aos objetivos do ambiente apresentados pela própria plataforma Google, que nos indica que essa ferramenta pode auxiliar professores e alunos "a organizar as tarefas, aumentar a colaboração e melhorar a comunicação" (Google, 2020), consequentemente melhorando a metodologia e a aprendizagem. Dessa forma, "o Google Sala de aula economiza tempo e papel, além de facilitar a criação de turmas, distribuição de tarefas, comunicação e organização" (Google Play, 2019).

Silva e Neto (2018) colaboram que a principal característica do Google Sala de Aula está na "na ampliação do espaçotempo, o que torna o processo de aprendizagem contínuo e dinâmico" (Silva \& Netto, 2018, p.120). A capacidade de interação e comunicação, entre professor e alunos a qualquer tempo e local, ampliam o processo ensino aprendizagem para além do ambiente da sala de aula.

Assim, o ambiente virtual Google Sala de Aula pode ser muito enriquecedor, para fins pedagógicos, se for utilizado de maneira planejada, com o intuito de estabelecer "novas metodologias interativas onde se possa compartilhar materiais didáticos de forma dinâmica, bem como, propiciar a interação em tempo real entre professores e alunos" (Araújo, 2016, p. 18). Esse aspecto pode ser comtemplado ao se utilizar recursos inerentes desse ambiente cooperativo, tais como:

A capacidade para armazenamento de e-mails e arquivos ilimitada, o sistema de comunicação via e-mail, Gmail; a possibilidade de encaminhamento de mensagens instantâneas, via Hangouts; o calendário que permite trabalhar com agendamentos; a praticidade da ferramenta para ambiente de Sala de Aula; a possibilidade de criação de Websites e o incentivo à participação em redes sociais" (Araújo, 2016, p. 35).

Essa interação proporcionada pelos AVA, afirma Silva (2018), revolucionaram o processo ensino/aprendizagem, tornando-o mais dinâmico e interativo, pois possibilitam unir em um mesmo ambiente, diversas mídias e ferramentas, tais como textos, vídeos, fóruns e chats, entre outros. Tendo em vista, que estas disponibilizam "um conjunto de ferramentas que auxiliam na comunicação, no acesso, no controle dos usuários do sistema em geral e na aprendizagem dos alunos" (Silva, 2018, p. 7). 
Reis et al. (2019, p. 6) complementa que "a tecnologia é uma ótima ferramenta na fixação de conteúdo, principalmente daqueles com maior grau de dificuldade, entendimento e abstração". No entanto, Dias \& Chagas (2015, p. 394), nos esclarecem que,

Os processos biológicos, na sua maioria, são caracterizados por uma grande complexidade, são difíceis de visualizar, permanecendo invisíveis a olho nu, de duração demasiado lenta ou rápida, exigindo ao aluno um nível de abstração assinalável na construção de modelos mentais para a sua compreensão, o que não é fácil.

Isso pode explicar o fato de uma aluna ter relatado sentir dificuldade em apreender por ser uma plataforma on-line, não sendo concreto no caderno.

Para um aluno o ambiente não contribui para a aprendizagem, devido ao tempo de realização das atividades, gerando atrasos no andamento das aulas. Na realidade este aspecto levantando pelo aluno está mais relacionado ao desenvolvimento das simulações e atividades, devido a problemas como o acesso à internet e/ou o mal funcionamento do laboratório, do que ao ambiente Google propriamente dito, nos quais as atividades e simulações estavam postadas.

Nesse mesmo sentido, ao ser solicitado aos alunos que indicassem os principais aspectos positivos na utilização do ambiente Google Sala de Aula para a aprendizagem, primeiramente, seis alunos indicaram ser um facilitador da aprendizagem; três mencionaram ser a diversificação metodológica com o uso dos recursos tecnológicos; três apontaram a organização e praticidade proporcionadas pelo ambiente; e três, a comunicação propiciada pela interação dos alunos entre si e também com a professora (Gráfico 2).

Gráfico 2 - Aspectos positivos na utilização do ambiente Google Sala de Aula para a aprendizagem.

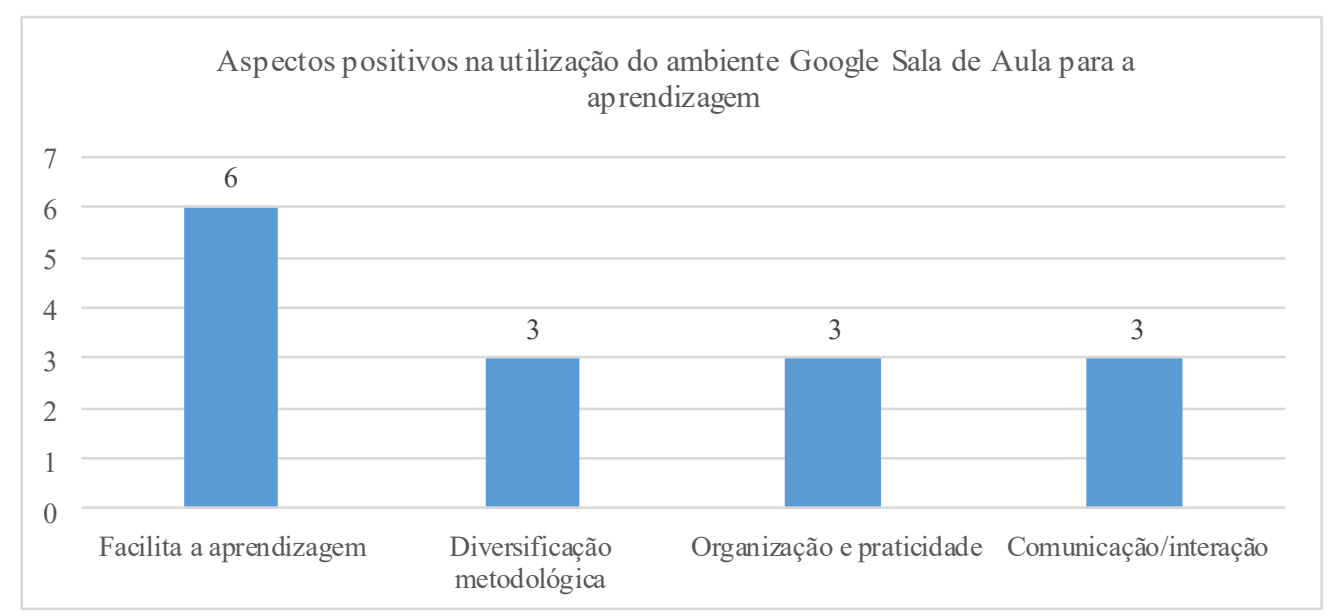

Fonte: Autores (2020).

Souza e Souza (2016, p. 11) afirmam que a implementação de plataformas online no ensino médio tende a "despertar o interesse dos alunos pela disciplina que está sendo estudada, consequentemente, haverá uma interação maior entre os alunos, aumentando assim o espaço colaborativo entre eles, contribuindo no processo de ensino e aprendizagem".

De modo que, entre os vários benefícios apresentados pela plataforma, Silva e Neto (2018, p. 9) destacam: fácil configuração, visto que os professores podem cadastrar uma turma e convidar alunos e professores auxiliares e no mural da turma, eles podem compartilhar informações, como tarefas, avisos e perguntas; o poupar tempo e papel, pois os professores podem distribuir tarefas, se comunicar e manter a organização em um único lugar; a organização, tendo em vista que os alunos podem visualizar as tarefas pendentes no mural ou na agenda da turma, e todos os materiais ficam automaticamente salvos em pastas do Google Drive; comunicação e feedback aprimorados, sendo que os professores podem criar tarefas, enviar avisos, 
iniciar instantaneamente debates com a turma e os alunos podem compartilhar recursos uns com os outros e interagir no mural da turma ou por e-mail; além disso, os professores também podem visualizar rapidamente quem concluiu ou não um trabalho, dar feedback direto em tempo real e atribuir notas; funciona com aplicativos, tais como Docs Google, Google Agenda, Gmail, Google Drive, Google Forms; entre outros.

Silva e Netto (2018, p. 120), acrescentam ainda, que o uso desta plataforma permite que o professor possa "gerenciar conteúdo, simplificar a criação, distribuição e avaliação de trabalhos escolares, bem como características de interatividade e colaboração entre os agentes do processo de aprendizagem". Essas funções existentes na plataforma, acrescentam os autores, favorecem a troca de conhecimentos entre os participantes do processo pelas diversas formas de comunicação entre eles.

Esses vários recursos do ambiente, possibilitam tanto a organização por parte de professores e alunos, quanto o aumento da comunicação entre os envolvidos, influenciando de forma direta na metodologia adotada nas aulas. Especificamente o Google Sala de Aula ou Classroom, além das possibilidades de um ambiente virtual de aprendizagem, favorece a sincronização e a utilização de outras ferramentas e recursos da plataforma Google, tais como Google Drive, Google Apresentações, Google Documentos, Google Planilhas, Google "Meet", Google Mapas, Google Formulários, Calendários, entre outros. Por isso, se utilizado de forma planejada, buscando "novas metodologias interativas onde se possa compartilhar materiais didáticos de forma dinâmica, bem como, propiciar a interação em tempo real entre professores e alunos" (Araújo, 2016, p. 18), torna-se um ambiente pedagogicamente enriquecedor.

Esse aspecto foi ressaltado também por Prandini (2009), ao afirmar que essa tecnologia pode expandir a capacidade de comunicação entre professores e alunos, aumentando as dimensões de espaço e tempo em que essa interação pode ocorrer, tanto de forma síncrona ou assíncrona, oportunizando modalidades comunicativas distintas.

A relação entre teoria e prática, apontada pela aluna A2, pode favorecer uma aula mais dinâmica que "estimule o interesse dos alunos e os levem a resolver os problemas que devem emergir das próprias atividades, organizadas e orientadas pelo professor para a compreensão de um conceito de genética e dos procedimentos envolvidos" (Cruz, 2018, p. 9).

Silva (2018) nos aponta o quanto o ambiente Google Sala de Aula pode contribuir com uma metodologia ativa, favorecendo a aplicação de novas práticas pedagógicas; podendo servir de base para o professor em sala de aula, utilizar diferentes mídias; proporcionando atividades diversificadas, tornando assim, a aula mais interativa, colaborativa, e autêntica para o educando, propiciando a aprendizagem significativa.

Quanto aos aspectos negativos na utilização do ambiente Google Sala de Aula para a aprendizagem, dez alunos revelaram ser a dificuldade de acesso à internet, visto que a plataforma só funciona on-line; três mencionaram as dificuldades no uso dos recursos do ambiente; e dois afirmaram não terem nenhum aspecto negativo (Gráfico 3). 
Gráfico 3 - Aspectos negativos na utilização do ambiente Google Sala de Aula para a aprendizagem.

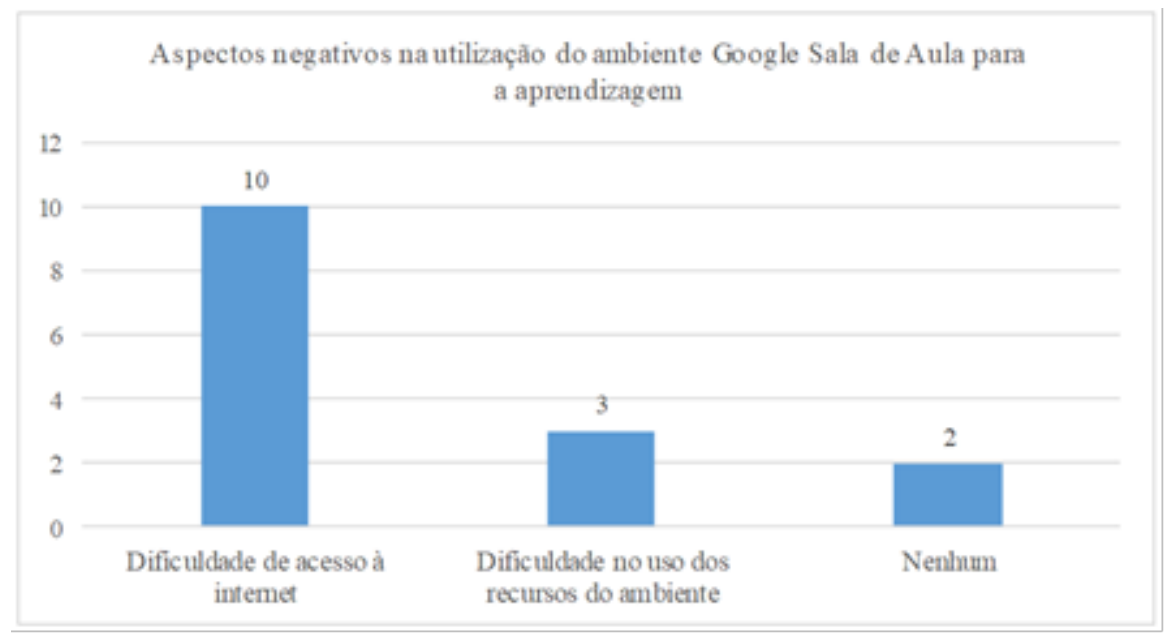

Fonte: Autores (2021).

Essa mesma dificuldade com o acesso à internet é apontada por Souza e Souza (2016), numa pesquisa que realizaram sobre o "Uso da Plataforma Google Classroom como ferramenta de apoio ao processo de ensino e aprendizagem: relato de aplicação no ensino médio", na qual constatam:

Mesmo com o avanço das novas tecnologias, ainda existem algumas barreiras que tornam o uso dessas tecnologias pouco praticada nas escolas do ensino médio, a exemplo pela falta de laboratórios de informática nas escolas ou laboratórios defasados e o acesso à internet ainda ser um pouco limitado em questão de velocidade de navegação que foi um problema detectado através desta pesquisa (Souza \& Souza, 2016, p. 11).

Dessa maneira, o ambiente apresenta algumas desvantagens, entre as quais, a falta de estrutura na "disponibilização dos recursos, sendo prático apenas para atividades do dia a dia, a dependência do funcionamento da Internet, a obrigatoriedade de existir um domínio associado às Google Apps Educação e a obrigatoriedade de os alunos possuírem um e-mail institucional" (ARAÚJO 2016, p. 36). Portanto, é necessário que o professor conheça bem a ferramenta que irá utilizar, assim como a estrutura de suporte para esse uso.

Nesse aspecto, nos alerta Gianotto (2016), sobre a importância de se conhecer "as formas de uso da tecnologia computacional e da internet em processos educacionais e a compreensão sobre os potenciais e as limitações das ferramentas/recursos de informática no ensino [...]" (Gianotto, 2016, p. 14). Para isso é necessário que o professor explore o ambiente antes da realização da realização das aulas, conhecimento seus recursos e aplicativos. Existem na internet vários tutoriais e cursos on-line sobre a plataforma e suas diversas possibilidades de utilização.

O segundo obstáculo relatado pelos alunos contempla a complexidade no uso dos recursos do ambiente, citando por exemplo: "Porque as vezes tínhamos dificuldades em salvar ou finalizar as atividades e o conteúdo as vezes era fácil de entender pelo aplicativo", "A forma de entregar os trabalhos"; "Algumas ferramentas difíceis de manusear", na realidade contemplam desafios inerentes ao uso das animações e simulações, e não propriamente do ambiente Google Sala de Aula.

\section{Conclusão}

A utilização dos recursos tecnológicos como os ambientes virtuais de aprendizagem em sala de aula oportuniza a interação, a discussão, o aprofundamento de determinados temas, conteúdos e conceitos nas mais diversas áreas do conhecimento. São ferramentas que auxiliam na mediação professor/aluno para o processo ensino e aprendizagem, 
contribuindo na investigação dos conhecimentos prévios dos alunos, na elaboração de conceitos e do conhecimento, bem como, na transposição para o conhecimento científico.

$\mathrm{O}$ uso de ambientes virtuais de aprendizagem, também podem exercer um papel fundamental na efetivação da aprendizagem, pois possibilitam a postagem de materiais nos mais variados formatos (vídeos, imagens, textos, animações, infográficos, mapas, tabelas, entre outros), além de possibilitar a interação em tempo síncrono e assíncrono entre os diversos participantes por meio de ferramentas, tais como chats, fóruns, diários de bordo, etc. Essa relação tornou o processo ensino/aprendizagem mais dinâmico e interativo, sendo estes ambientes possuem uma dinâmica pedagógica especifica, possibilitando "vincular conteúdos de forma virtual, são como um terreno fértil de significações e interações, onde humano e as tecnologias interagem, potencializando a construção de conhecimento" (Rolim \& Scaramuzza, 2016. p. 186).

Por ser um AVA, o Google Sala de Aula permite ao professor alocar em seu interior materiais de sua própria autoria, construindo um espaço de aprendizagem a partir dos seus objetivos de ensino. Não se trata de um espaço pronto, mas de um ambiente para a construção coletiva do processo de ensino e aprendizagem.

Diante das vantagens apontadas pelos alunos tais como: facilitar a aprendizagem; possibilitar uma diversificação metodológica ao aliar o uso dos recursos tecnológicos; a organização e praticidade do ambiente; e a comunicação interação aluno/aluno e alunos/professora. E levando em consideração também, as desvantagens indicadas entre as quais a dificuldade de acesso à internet e de uso dos recursos do ambiente; pode-se considerar que seu uso apresenta mais vantagens, do que desvantagens, sendo ainda que as primeiras podem ser aprimoradas e as segundas corrigidas e melhoradas.

Deveras, ressaltamos que o ambiente virtual Google Sala de Aula pode ser muito enriquecedor, para fins pedagógicos, se for utilizado de maneira planejada, pois segundo os alunos facilitam a aprendizagem, possibilitam uma diversificação metodológica; auxiliam na organização de conteúdos e na interação entre os participantes.

Dessa forma, o ambiente Google Sala de Aula pode contribuir com os professores nas mais diversas áreas, principalmente na atualidade, em que essa plataforma vem sendo utilizado com maior intensidade, tanto na educação à distância propriamente dita, como na forma de ensino hibrido, mesclando aula presenciais, com atividades na plataforma.

Uma das possibilidades de continuação da pesquisa seria a investigação junto aos professores de Biologia da Educação Básica, sobre quais as vantagens e fragilidades do uso do Google Sala de Aula no ensino remoto e hibrido, adotados neste período de pandemia.

\section{Referências}

Amaral, J. F. (2007). Como fazer uma pesquisa bibliográfica. Faculdade de Medicina, Universidade Federal do Ceará https://cienciassaude.medicina.ufg.br/up/150/o/Anexo_C5_Como_fazer_pesquisa_bibliografica.pdf.

Araújo, D. L. de. (2013). O que é (e como faz) sequência didática? Entrepalavras, Fortaleza - 3, 322-334, http://www.entrepalavras.ufc.br/revista/index.php/Revista/article/view/148/181.

Araújo, H. M. C. (2016). O uso das ferramentas do aplicativo "Google sala de aula" no ensino de matemática. 93 f. Dissertação (Programa de Mestrado Profissional em Matemática) - Universidade Federal de Goiás, Catalão, 2016. https://repositorio.bc.ufg.br/tede/handle/tede/6470?mode=full\#preview-link0.

Bilthauer, M. I. \& Takasusuki, M. C.C.R. (2012). Objetos de aprendizagem como recurso didático no processo ensino-aprendizagem de genética. In: O professor PDE e os desafios da escola pública paranaense - 2012. http://www.diaadiaeducacao.pr.gov.br/portals/cadernospde/pdebusca/produ coes pde/2012/2012 uem bio artigo marisa ines bilthauer.pdf.

Brasil. Ministério da Educação. Base Nacional Comum Curricular. (2018). http://basenacionalcomum.mec.gov.br/images/BNCC_EI_EF_1105 18_versaofinal_site.pdf.

Coll, C., \& Monereo, C. (2010). Psicologia da educação virtual: aprender e ensinar com as tecnologias da informação e da comunicação. Porto Alegre: Artmed, 2010.

Cruz, J. F. (2018). Aprendizagem Significativa em genética por meio de modelos didáticos. Anais do $11^{\circ}$ Encontro Internacional de Formação de Professores - ENFOPE. Aracajú, 11, https://eventos.set.edu.br/index.php/enfope/article/view/8989/4006.

Dias, C. P. \& Chagas, I. (2015). Multimídia como recurso didático no ensino da Biologia. Interacções. 393-404 (2015). file://C:/Users/Marisa/Downloads/8746-Texto\%20do\%20Trabalho-24750-1-10-20160305\%20(2).pdf. 
Research, Society and Development, v. 10, n. 8, e1710817097, 2021

(CC BY 4.0) | ISSN 2525-3409 | DOI: http://dx.doi.org/10.33448/rsd-v10i8.17097

Ferreira, José L. (2010). Moodle: um espaço de interação e aprendizagem. In: COSTA, Maria L.F.; ZANATTA, Regina M. Educação a Distância no Brasil: aspectos históricos, legais, políticos e metodológicos. Maringá: Eduem.

Gianotto, D. E. P. (2016). Possibilidades, contribuições e desafios das ferramentas da informática no ensino das ciências. CRV.

Google Play. (2019). Gloogle Classroom. https://play.google.com/store/apps/details?id=com.google.android.apps.classroom\&hl=pt_BR.

Google. (2020). For education. https://edu.google.com/intl/pt-BR/products/classroom/?modal_active=none.

Hamze, A. (2020). As TICS na prática Pedagógica. https://educador.brasilescola.uol.com.br/trabalho-docente/as-tics-na-pratica-pedagogica.htm. Kenski, V. M. (2012). Educação e tecnologias: o novo ritmo da informação. Papirus.

Lima, V. R. et al. Metodologias ativas de ensino e aprendizagem: sala de aula invertida, instrução por colegas e júri simulado no ensino de Matemática. Research, Society and Development, 10(5). https://rsdjournal.org/index.php/rsd/article/view/14507/13096

Mauri, T. \& Onrubia, J.O. (2010). O professor em ambientes virtuais: perfis, condições e competências. In.: Coll, C. et al. Psicologia da educação virtual: aprender e ensinar com as tecnologias da educação e comunicação. Artmed. P. 118-125.

Miranda, G. L. (2007). Limite e possibilidades das TIC na educação. In: Sísifo/Revista de Ciências da Educação http://ticsproeja.pbworks.com/f/limites+e+possibilidades.pdf.

Moraes, R.; \& Galliazzi, M. C. (2011). Análise Textual Discursiva. (2a ed.), Unijúi. Ijúi.

Moreira, M. A. (1999). Teorias de Aprendizagem. EPU.

Moreira, J. M. B. (2018). TIC: uma investigação na formação de professores e na transposição didática. Tese. www.pcm.uem.br/uploads/jussany-maria-debarros-moreira--17082018_1540403934.pdf.

Pelizzari, A. et al. (2002) Teoria da Aprendizagem Significativa segundo Ausubel. Revista PEC. Programa Educação Corporativa, 2, 37-42. http://portaldoprofessor.mec.gov.br/storage/materiais/0000012381.pdf.

Pereira, A. T. (2007). Ambientes virtuais de aprendizagem em diferentes contextos. Ciência Moderna.

Prandini, R. C. (2009). Formação do formador para a atuação docente mediatizada pelas tecnologias da informação e comunicação. In: HESSEL, A.; PESCE, L.; ALLEGRETTI, S. Formação online de educadores: identidade em construção. São Paulo: RG Editores, p. 63-88.

Reis, T. A. et al.. (2010). $O$ ensino de genética $e \quad$ a atuação da mídia. http://connepi.ifal.edu.br/ocs/index.php/connepi/CONNEPI2010/paper/viewFile/851/574. 2010.

Rocha, S. C. (2016). O lúdico no ensino da genética. In: Os desafios da escola pública paranaense na perspectiva do professor PDE: produções didáticopedagógicas 2016. http://www.diaadiaeducacao.pr.gov.br/portals/cadernospde/pdebusca/producoes_pde/2016/2016_pdp_bio_ufpr_silvanacruzdarocha.pdf

Rolim, A. T. \& Scaramuzza, B. C. (2016). Aprendizagem significativa em ambientes virtuais de aprendizagem. POIÉSIS: Revista do Programa de PósGraduação em Educação - Mestrado _universidade do Sul de Santa Catarina. Unisul, Tubarão, 10, 182 - 195, Unisul.

Sá Filho, C. S. \& Machado, E. C. (2003). O computador como agente transformador da educação e o papel do objeto de aprendizagem. http://www.abed.org.br/seminario2003/texto11.htm.

Silva, E. C. S. (2018). O Google Sala de Aula como interface de aprendizagem no ensino superior. In: $9^{\circ}$ Simpósio Internacional de Educação e Comunicação - SIMEDUC. 17 a 19 de outubro de 2018. UNIT. Aracajú. https://eventos.set.edu.br/index.php/simeduc/article/viewFile/9572/4164.

Silva, G. L. \& Netto, J. F. M. (2018). Um relato de experiência usando Google Sala de Aula para apoio à aprendizagem de química. VII Congresso Brasileiro de Informática na Educação (CBIE 2018). Anais do XXIV Workshop de Informática na Escola (WIE 2018). https://pdfs.semanticscholar.org/9cfb/0a655258d5e798361a2c37e9444c735d136e.pdf.

Silva. M. (2010). Educar na Cibercultura: desafios à formação de professores para docência em cursos online. Revista digital de tecnologias cognitivas. n. 3 jan/jun 2010. https://www4.pucsp.br/pos/tidd/teccogs/artigos/2010/edicao_3/3-educar_na_cibercultura-desafios_formacao_de_professores_para_docencia_ em_cursos_online-marco_silva.pdf. Acesso em 20 fev. 2020.

Souza, A. \& Souza, F. (2016) Uso da Plataforma Google Classroom como ferramenta de apoio ao processo de ensino e aprendizagem: relato de aplicação no ensino médio. https://repositorio.ufpb.br/jspui/bitstream/123456789/3315/1/ACSS30112016.pdf.

Valente, J. A (2009). Análise dos diferentes tipos de softwares usados na Educação. 2009. http://www.nuted.ufrgs.br/edu3375_2009_2/links/s emana_3/analise_soft.pdf. 